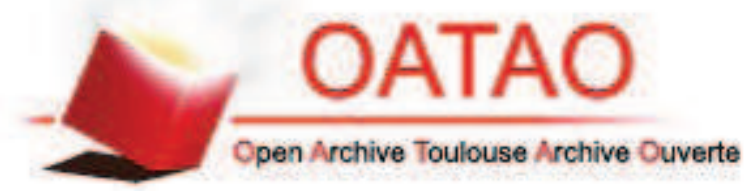

This is an author-deposited version published in : http://oatao.univ-toulouse.fr/ Eprints ID : 10804

To link to this article : DOI: 10.1016/j.biortech.2007.08.082 http://dx.doi.org/10.1016/ j.biortech.2007.08.082

To cite this version: Eyheraguibel, Boris and Silvestre, Jérôme and Morard, Philippe Effects of humic substances derived from organic waste enhancement on the growth and mineral nutrition of maize. (2008) Bioresource Technology, vol. 99 ( $\left.\mathrm{n}^{\circ} 10\right)$. pp. 4206-4212. ISSN 0960-8524

Any correspondance concerning this service should be sent to the repository administrator: staff-oatao@listes-diff.inp-toulouse.fr 


\title{
Effects of humic substances derived from organic waste enhancement on the growth and mineral nutrition of maize
}

\author{
B. Eyheraguibel *, J. Silvestre, P. Morard \\ Laboratoire Agronomie Environnement Ecotoxicologie, Ecole Nationale Supérieure d'Agronomie de Toulouse, Av. de l'Agrobiopôle, \\ 31326 Castanet Tolosan Cedex, France
}

\begin{abstract}
A physico-chemical process has been developed to transform and enhance lignocellulosic waste in liquid humic extracts: humic-like substances (HLS). The aim of this study was to determine the effects of HLS on plant physiology in order to consider their agricultural use as organic fertilizers. The effects of HLS were evaluated on maize seed germination, and their impact on growth, development and mineral nutrition was studied on maize plants cultivated under hydroponic conditions. The experimental results showed that HLS do not increase the percentage and rate of germination but enhance the root elongation of seeds thus treated. Positive effects were also observed on the whole plant growth as well as on root, shoot and leaf biomass. These effects can be related to the high water and mineral consumption of plants undergoing this treatment. The high water efficiency indicated that such plants produce more biomass than non-treated plants for the same consumption of the nutrient solution. Furthermore, the use of HLS induced a flowering precocity and modified root development suggesting a possible interaction of HLS with developmental processes. Considering the beneficial effect of HLS on different stages of plant growth, their use may present various scientific and economic advantages. The physico-chemical transformation of sawdust is an interesting way of enhancing organic waste materials.
\end{abstract}

Keywords: Humic substances; Waste enhancement; Maize; Whole plant growth; Hydroponic culture

\section{Introduction}

It has long been recognized that humic substances (HS) have many beneficial effects on soil and plant growth. These heterogeneous and complex molecules, ubiquitous in the environment, can produce various morphological, physiological and biochemical effects on higher plants (Chen and Aviad, 1990; Vaughan and Malcom, 1985). The influence of humic material on plant growth, have been investigated on biometric factors and numerous studies have shown that humic substances enhance root, leaf and shoot growth but also stimulate the germination of various crop species (Piccolo et al., 1993). These positive

\footnotetext{
* Corresponding author.

E-mail address: eyheragu@ensat.fr (B. Eyheraguibel).
}

effects are explained by the direct interaction of HS with physiological and metabolism processes (Nardi et al., 2002). The addition of HS increase nutrient uptake (Linehan, 1978), cell permeability (Vaughan and Ord, 1985) and modify mechanisms involved in plant growth stimulation (Lee and Bartlett, 1976).

Due to their properties, humic substances play a major role in soil fertilization. Many products of different origins (peat, compost, leonardite) are commonly used in agriculture to develop organic fertilization methods (Ayuso et al., 1996; Mayhew, 2004). For a number of years, various products containing humic acids have been commercialized for use on grass (Cooper et al., 1998), horticultural plants (Ribeiro et al., 2000) or crop production (Lee and Bartlett, 1976). In spite of positive influences on the plant growth of substances such as leonardite, (Brownell et al., 1987; Fernandez-Escobar et al., 1996), 
their use remains controversial because of their heterogeneity (Malcolm and MacCarthy, 1986). Nowadays, enhancement and recycling of organic waste by composting processes can be considered as the most efficient way to produce organic soil conditioners. Compost (Lulakis and Petsas, 1995; Raviv, 1998; Senesi, 1989), as well as vermicompost (Atiyeh et al., 2002; Atiyeh et al., 2001), are suitable and widely used in agriculture to enhance plant growth. However the composting process takes a long time to generate stable and mature products. To reduce composting time and to limit the heterogeneity of humic products, a physico-chemical process has been developed to enhance lignocellulosic waste and to produce a liquid organic fertilizer. The degradation and oxidation of wood waste was managed through fast, controlled and reproducible steps. The end product termed "humic-like substances" (HLS) presents similarity in composition, structure and properties with natural humic substances coming from soil and compost (Eyheraguibel et al., 2002; Richard, 2002). The objective of this work was to determine the physiological effects of HLS on maize seed germination and on vegetative growth and the development of maize plants cultivated under hydroponic conditions.

\section{Methods}

\subsection{Humic-like substance extraction}

Humic-like substances were obtained from the physicochemical degradation of homogeneous lignocellulosic raw materials. Poplar sawdust was heated under oxidizing alkaline conditions as described in Morard et al. (2005). Humic-like substances were extracted from sawdust with potassium hydroxide $(1 \mathrm{~N})$ for the duration of an hour. After centrifugation, a brown liquid extract was collected and adjusted to $\mathrm{pH} 7$ with nitric acid $(1 \mathrm{~N})$. This process avoids the complex mechanisms of natural humic substance genesis and leads to the production of reproducible and stable humic products (Table 1). The chemical analysis of humic and fulvic acid proportion, total organic carbon content and available nutrients were used to characterize the humic extract (Eyheraguibel, 2004). Humic acids

Table 1

Properties of humic like substances

\begin{tabular}{lc}
\hline & HLS \\
\hline $\mathrm{pH}$ & 6.8 \\
Total organic carbon $\left(\mathrm{g} \mathrm{l}^{-1}\right)$ & 9.36 \\
Humic Acids (\%) & 56.4 \\
Fulvic Acids (\%) & 43.6 \\
$E_{465} / E_{665}$ & 8.2 \\
Mineral content $\left(\mathrm{g}^{-1}\right)$ & \\
Potassium & 38.4 \\
Nitrate & 40.2 \\
Phosphate & 0.4 \\
Sulphate & 0.18 \\
Calcium & 0.04 \\
Magnesium & 0.005 \\
\hline
\end{tabular}

(HA) were precipitated by the acidification of the HLS extract to $\mathrm{pH} 1.0$ with concentrated $\mathrm{HCl}$. Precipitated HAs were separated from fulvic acids (FA) by centrifugation at $4000 \mathrm{rpm}$ for $20 \mathrm{~min}$ and redissolved in a sodium hydroxide solution $(0.1 \mathrm{M})$. Fulvic acids were obtained from the supernatant solution recovered after the precipitation of the humic acids. The total organic carbon content of HA and FA solutions was measured by the dichromate oxidation method (Walkley and Black, 1934). Spectrophotometric measurements were carried out with a Perkin Elmer Lambda 20 spectrometer using quartz cells. The $E_{4} / E_{6}$ ratios were calculated as the ratio of absorbance at 465 and at $665 \mathrm{~nm}$ according to Schnitzer and Khan (1972).

\subsection{Germination test}

To test the capacity of HLS to enhance germination, maize seeds (20 per application) were germinated on filter paper moistened by $10 \mathrm{ml}$ of a humic solution $(50 \mathrm{mg}$ of carbon per liter $\left(\mathrm{mg} \mathrm{C}^{-1}\right)$ dissolved in a nutrient solution; $\mathrm{pH}$ 5.0) or a classical nutrient solution as a reference solution. The nutrient solution was prepared in deionized water as follows: $4 \mathrm{mM} \mathrm{Ca}\left(\mathrm{NO}_{3}\right)_{2} ; 2 \mathrm{mM} \mathrm{KH}_{2} \mathrm{PO}_{4} ; 3 \mathrm{mM}$ $\mathrm{MgSO}_{4}, 11 \mathrm{mM} \mathrm{KNO} ; 15 \mathrm{ml} \mathrm{l}^{-1}$ FeEDTA; $0.52 \mathrm{ml} \mathrm{l}^{-1}$ $\mathrm{H}_{3} \mathrm{BO}_{4} ; 0.49 \mathrm{ml} \mathrm{l}^{-1} \mathrm{MnCl}_{2} ; 0.11 \mathrm{ml} \mathrm{l}^{-1} \mathrm{ZnCl}_{2} ; 0.06 \mathrm{ml} \mathrm{l}^{-1}$ $\mathrm{CuCl}_{2} ; 0.01 \mathrm{ml} \mathrm{l}^{-1} \mathrm{NaMoO}_{4}$ (Morard, 1995). HLS were applied by the addition of the initial humic liquid extract (9.36 $\left.\mathrm{g} \mathrm{C}^{-1}\right)$ in a nutritive solution to a rate of 0 and $50 \mathrm{mg} \mathrm{C}^{-1}$. The HLS solution was formulated according to nutrients supplied by undiluted HLS, so that both the reference and HLS solutions presented the same macronutrient input. The optimum dose of HLS ( $\left.50 \mathrm{mg} \mathrm{C}^{-1}\right)$ was previously determined by a screening test using $25,50,100$, 200, $500 \mathrm{mg} \mathrm{Cl}^{-1}$ (Eyheraguibel, 2004). The experiment was carried out in darkness at $25^{\circ} \mathrm{C}$ in a growth chamber for a period of two weeks. From the 3 rd to the 6 th day of incubation, the germination rate was calculated as described in Piccolo et al. (1993). The number of seeds in each dish showing radicle emergence were counted. The daily count was used to calculate the mean germination rate (MGR) as $\mathrm{N} i$ / T $i$ where $\mathrm{N} i$ is the number of germinated seeds on the $i$ th day and $\mathrm{T} i$ is the $i$ th counting day. The root elongation was measured daily for a period of 2 weeks. Then plants were washed with distilled water and harvested. Roots and shoots were separated for total fresh weight determination. The dry weight of seedlings was recorded after $48 \mathrm{~h}$ of drying in an oven at $70{ }^{\circ} \mathrm{C}$.

\subsection{Growth test}

In order to assess the effect of HLS on rooting, plant growth and development, hydroponic culture of maize seedling was carried out. The experiment took place in a greenhouse using maize seeds (Zea mays L.) pre-germinated for $72 \mathrm{~h}$ on filter paper moistened with distilled water. Forty maize seedlings (three days old) with uniform 
size and shape and a healthy aspect were selected and transferred into a $42 \mathrm{~L}$ culture tank containing an aerated standard solution to acclimatize the seedlings to hydroponic conditions. After 10 days, 20 maize seedlings of similar weight and height were transplanted, at the 2-3 leaf stage, into an opaque plastic container $(15 \mathrm{~L})$ containing an aerated treatment solution (one plant per container submerged in the nutrient solution). The nutrient solution was prepared as described previously for the germination test. The HLS was applied at the rate of 0 and $50 \mathrm{mg} \mathrm{C}^{-1}$ by the addition of an initial humic liquid extract $(9.36 \mathrm{~g} \mathrm{C}$ $1^{-1}$ ) in a nutritive solution. The solution was formulated according to the nutrients supplied by undiluted HLS to obtain a reference and treatment solution with an equal composition. The optimum dose of $\operatorname{HLS}\left(50 \mathrm{mg} \mathrm{C}^{-1}\right)$ was previously determined by a screening test (Eyheraguibel, 2004). The $\mathrm{pH}$ of the HLS solution was adjusted to $6.0 \pm 0.5$ with a small amount of nitric acid $(0.1 \mathrm{~N})$ inducing negligible effects on nutrient content. The electrical conductivity was $2.45 \mathrm{mS} / \mathrm{cm}$. The experiment was carried out in a greenhouse, during two months, for a $16-\mathrm{h}$ period of light $\left(25^{\circ} \mathrm{C}\right)$ and an 8 -h period of darkness $\left(16^{\circ} \mathrm{C}\right)$. Nutrient solutions were continuously aerated and filled weekly to a quantity of $15 \mathrm{~L}$ with distilled water in order to record water consumption and to monitor $\mathrm{pH}$ and electrical conductivity to monitor culture conditions. After 2 months of application, plant heights (roots and stems) were measured from the 5th node to the plant tip and the total leaf number was recorded. The harvest date was determined as is usually done in agricultural practice, at green maturity in the early stage of cob filling. Plants were harvested and separated into leaves, stems and roots for fresh weight determination of each organ. The samples were dried for $48 \mathrm{~h}$ in an oven at $70^{\circ} \mathrm{C}$ for dry weight determination.

\subsection{Mineral nutrient analysis}

To determine if HLS enhanced nutrient uptake, the nutrient depletion from solutions was measured at the end of the two-month experimentation period. Plant samples were ground in a Wiley mill to a particle size of 1 $\mathrm{mm}$ and then analyzed for their mineral content following dry ashing. Macronutrient $(\mathrm{P}, \mathrm{K}, \mathrm{Ca}, \mathrm{S})$ content were determined by HPLC (Dionex $\left.{ }^{\circledR} \mathrm{DX} 100\right)$ except for nitrogen which was determined using a Leco CHN elemental analyzer. Microelements were analyzed by atomic absorption spectrometry (Perkin Elmer). The mineral analysis results are given in tissue concentrations (tissue content as a percentage of dry weight) and quantities (the consumption of nutrient elements in $\mathrm{mg}$ ) of each element in order to present both physiological and agronomical data.

\subsection{Statistical analysis}

The experimental designs were a randomized complete block with 20 repetitions for the germination test and 10 repetitions for plant experiments. All data was analyzed statistically by a one-way ANOVA method using the SigmaStat $($ ) software package and considering the treatment as the independent variable. The mean (of each parameter measured) was evaluated statistically by Tuckey's test considering a significance level of $P \geqslant 0.05$ throughout the study.

\section{Results}

\subsection{Humic-like substance characterization}

The general properties of humic-like substances are shown in Table 1. The HLS end-product is a black liquid presenting a high organic carbon content $\left(9.36 \mathrm{~g} \mathrm{C}^{-1}\right)$. The product is constituted by humic acids (56.4\%) and a high level of fulvic acid $(43.6 \%)$ confirmed by a high $E_{465} / E_{665}$ ratio characteristic of low molecular weight content (Chen et al., 1977) (Table 1). As demonstrated by Richard (2002), HLS properties and behaviour are similar to natural humic substance properties extracted from soil or compost. Elemental analysis and infrared spectroscopy indicate similarities in the composition and structure of humic molecules. Gel filtration data and spectrophotometric analysis confirmed the presence of high and low molecular weight particles (Richard, 2002).

\subsection{Effects of HLS on germination seeds}

The effects of HLS on seed germination and root elongation are presented in Fig. 1 and Table 2. No increase was observed in the number of germinated seed. The germination started 3 days after sowing and the first daily count of germinated seed showed more radicle emergence for the non-treated seed. However the mean germination rate

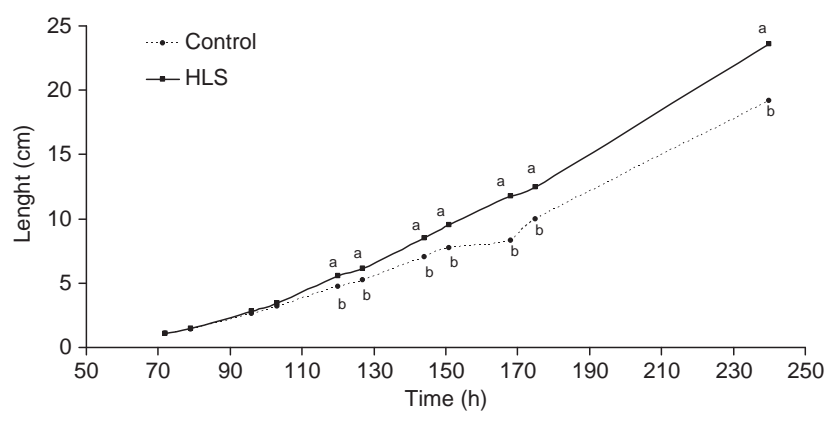

Fig. 1. Kinetic of roots elongation.

Table 2

The effect of humic-like substances on germination

\begin{tabular}{llll}
\hline Treatment & $\begin{array}{l}\text { Germination } \\
\text { rate }(\%)\end{array}$ & $\begin{array}{l}\mathrm{MGR}^{1} 3 \text { days } \\
\text { after sowing }\end{array}$ & $\begin{array}{l}6 \text { days after } \\
\text { sowing }\end{array}$ \\
\hline Control & 95 & $5.6 \mathrm{~b}$ & $4.51 \mathrm{a}$ \\
HLS & 90 & $5.0 \mathrm{a}$ & $4.58 \mathrm{a}$ \\
\hline
\end{tabular}

1 MGR: Mean germination rate. 
after 6 days of incubation was not significantly different from the control plants and monitoring by Piccolo et al. (1993), the humic application seemed to slow down the rate of germination. During the first four days after germination there was no significant difference between root elongation of treated and non-treated seeds. The root length of treated seeds increased progressively and significantly $(+18 \%)$ after 5 days of germination $(120 \mathrm{~h})$ and increased up to $25 \%$ more after 10 days $(240 \mathrm{~h}$ ) of treatment (Fig. 1).

\subsection{Effects of HLS on plant growth}

The positive effects of HLS were also observed on the whole plant growth. The biometric factors of harvested maize are presented in Table 3. After two months of experiments, treated plants exhibited a significant increase in total biomass, about $66 \%$ more fresh weight and $85 \%$ more dry weight. These effects were related to the increase of the fresh and dry weight of each plant organ. HLS primarily enhance the production of shoot, then leaf and root biomass. The most significant growth was recorded for shoot dry weight and corresponded to a twofold increase in plant shoot biomass. The formation of flowers was noticed only in treated plants. Furthermore, the humic treatment presented positive effect on shoot and root length with a significant increase of $72 \%$ and $25 \%$, respectively.

\subsection{Effects of HLS on development stages}

Humic treatment improved not only growth factors but also may influence the development of maize plants. Signif-

Table 3

Effect of humic-like substances on biometric factors

\begin{tabular}{|c|c|c|c|}
\hline & Control & HLS & $\%$ of control \\
\hline \multicolumn{4}{|l|}{ Fresh weight (g) } \\
\hline Roots & $94 \mathrm{a}$ & $139.9 \mathrm{~b}$ & 48.8 \\
\hline Shoots & $297 \mathrm{a}$ & $475 \mathrm{~b}$ & 60 \\
\hline Leaves & $98 \mathrm{a}$ & $154.2 \mathrm{~b}$ & 57.3 \\
\hline Flowers $^{1}$ & $0 \mathrm{a}$ & $44.6 \mathrm{~b}$ & - \\
\hline Total & 489 a & $813.8 \mathrm{~b}$ & 65.8 \\
\hline \multicolumn{4}{|l|}{ Dry weight ( $g$ ) } \\
\hline Roots & $15.9 \mathrm{a}$ & $21.6 \mathrm{~b}$ & 35.8 \\
\hline Shoots & $54.5 \mathrm{a}$ & $109.1 \mathrm{~b}$ & 100.2 \\
\hline Leaves & $25.2 \mathrm{a}$ & $38.6 \mathrm{~b}$ & 53.2 \\
\hline Flowers $^{1}$ & $0 \mathrm{a}$ & $6.8 \mathrm{~b}$ & - \\
\hline Total & $95.6 \mathrm{a}$ & $176.1 \mathrm{~b}$ & 84.2 \\
\hline \multicolumn{4}{|l|}{ Length $(\mathrm{cm})$} \\
\hline Roots & $63.1 \mathrm{a}$ & $77.6 \mathrm{a}$ & 23 \\
\hline Shoots & $102 \mathrm{a}$ & $176 \mathrm{~b}$ & 72.5 \\
\hline \multicolumn{4}{|c|}{ Number of leaves and flowers } \\
\hline Leaves & $13.4 \mathrm{a}$ & $15.1 \mathrm{~b}$ & 12.7 \\
\hline Cobs ( $q$ flower) & $0 \mathrm{a}$ & $1.6 \mathrm{~b}$ & - \\
\hline Staminates ( $\hat{0}$ flower) & $0.8 \mathrm{a}$ & $1 \mathrm{~b}$ & 25 \\
\hline
\end{tabular}

Mean in the same line followed by the same letter are not significant $(P=0.05)$.

${ }^{1}$ Represent total of male and female flower. icant differences in the number of leaves and flowers occurred at the end of the experiment. HLS increased the number of leaves up to $12 \%$. The number of staminates (male flowers) of treated plants was $25 \%$ higher than those plants grown in the reference solution. HLS application enhanced flowering during plant development as well as at harvest time only treated plants present cobs (Table 3). Furthermore, plants cultivated with the HLS solution produced more than one cob per plant. This enhancement in organ production underlines the effects of HLS on the precocity of some developmental processes.

Moreover, in the presence of humic fraction, the plant root development was modified (Fig. 2). Treated plants exhibited a high proliferation of lateral roots compared to plants grown in the reference solution which presented a less important initiation of adventive roots. In agreement with O'Donnell (1972) roots grown in the reference solution were long and unbranched whereas those grown in the humic solution present a profusion of small lateral roots. Similarly, Canellas et al. (2002) reported that humic treatment produced a hyperinduction of lateral root site emergence on maize plants. The elongation and proliferation of these secondary roots induce an increase of total radicular length and root surface area.

\subsection{Effects of HLS on mineral nutrition}

The nutrient solution consumption of maize plants treated with HLS was higher than that of plants grown in the reference solution (Table 4). The mean quantity of water consumption was $23.7 \mathrm{~L}$ per plant with the HLS treatment versus $16.2 \mathrm{~L}$ for the reference solution. On the other hand the water efficiency of these plants (calculated by dividing

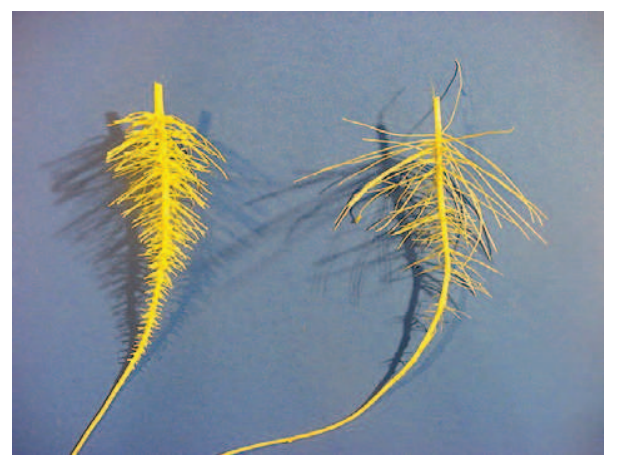

Fig. 2. Effect of HLS (left) on lateral root emergence in comparison with control (right).

Table 4

Effects of HLS on water consumption and water efficiency

\begin{tabular}{lll}
\hline & $\begin{array}{l}\text { Water } \\
\text { consumption }(\mathrm{l})\end{array}$ & $\begin{array}{l}\text { Water efficiency } \\
\text { (g dry weight } / 1 \text { water) }\end{array}$ \\
\hline Control & $16.2 \mathrm{a}$ & $5.9 \mathrm{a}$ \\
HLS & $23.7 \mathrm{~b}$ & $7.4 \mathrm{~b}$ \\
Gain (\% of control) & 46.5 & 25.4 \\
\hline
\end{tabular}




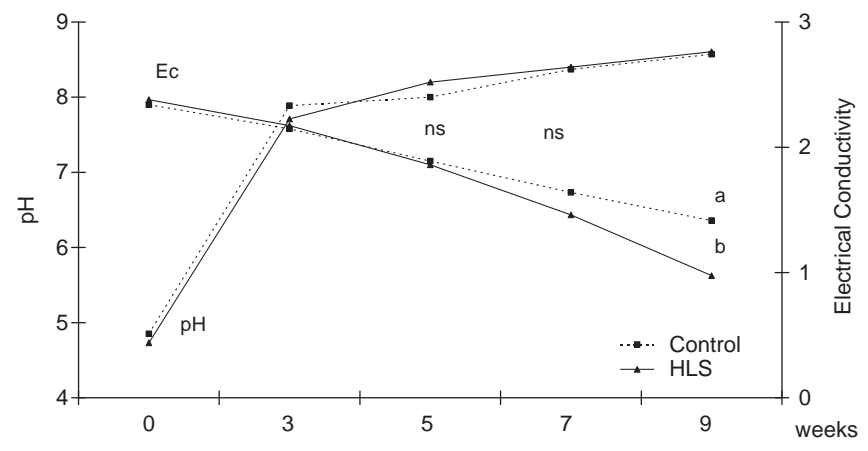

Fig. 3. Evolution of $\mathrm{pH}$ and electrical conductivity of nutrients solutions.

grams of the final plant dry weight per liter of water uptake during experiments) was significantly increased. This indicates that for the same water consumption, treated plants produced $25 \%$ more of biomass than control plants (Table 4). The evolution of the electrical conductivity (EC) is related to total ion concentration. The EC of a solution containing HLS was reduced compared to the reference solution (Fig. 3). The lower EC of the humic solution indicated that the application of the humic extract induced an

Table 5

Depletion of nutrient solutions and nutrient uptake during maize growth

\begin{tabular}{llllll}
\hline & \multicolumn{2}{c}{ Final nutrient solution composition $\left(\mathrm{mg}^{-1}\right)$} & & \multicolumn{2}{c}{ Plant uptake $(\mathrm{mg})$} \\
\cline { 2 - 3 } & Control & HLS & & Control & HLS \\
\hline Macroelements & & & & \\
$\mathrm{K}$ & $347.05 \mathrm{~b}$ & $225.21 \mathrm{a}$ & $3710 \mathrm{a}$ & $4410 \mathrm{a}$ \\
$\mathrm{Ca}$ & $140.00 \mathrm{a}$ & $137.00 \mathrm{a}$ & $670 \mathrm{a}$ & $1190 \mathrm{a}$ \\
$\mathrm{Mg}$ & $31.56 \mathrm{~b}$ & $27.77 \mathrm{a}$ & & $130 \mathrm{a}$ & $120 \mathrm{a}$ \\
$\mathrm{N}$ & $94.48 \mathrm{~b}$ & $65.02 \mathrm{a}$ & $1930 \mathrm{a}$ & $4000 \mathrm{~b}$ \\
$\mathrm{~S}$ & $184.87 \mathrm{~b}$ & $153.03 \mathrm{a}$ & $540 \mathrm{a}$ & $570 \mathrm{a}$ \\
$\mathrm{P}$ & $15.19 \mathrm{~b}$ & $11.96 \mathrm{a}$ & $970 \mathrm{a}$ & $1080 \mathrm{a}$ \\
$\mathrm{Microelements}$ & & & \\
$\mathrm{Cu}$ & $0.034 \mathrm{a}$ & $0.037 \mathrm{a}$ & $0.38 \mathrm{a}$ & $0.62 \mathrm{a}$ \\
$\mathrm{Mn}$ & $0.105 \mathrm{~b}$ & $0.088 \mathrm{a}$ & $2.96 \mathrm{a}$ & $4.3 \mathrm{~b}$ \\
$\mathrm{Zn}$ & $0.263 \mathrm{~b}$ & $0.148 \mathrm{a}$ & & $0.86 \mathrm{a}$ & $1.53 \mathrm{a}$ \\
$\mathrm{Fe}$ & $12.56 \mathrm{~b}$ & $10.25 \mathrm{a}$ & $23.08 \mathrm{a}$ & $28.51 \mathrm{~b}$ \\
\hline
\end{tabular}

increase in the nutrient uptake. This result was confirmed by the determination of the nutrient element depletion of the reference and HLS solutions which was estimated by the measurement of the final contents of each solution (Table 5). Macroelements (K, N, P, Mg and S) and microelements $(\mathrm{Mn}, \mathrm{Zn}$ and $\mathrm{Fe})$ of the humic solution decreased from $15 \%$ to $30 \%$ according to the element. This result can be related to the greatest solution consumption of treated plants. Conversely, plant sample analysis indicates the uptake of nutrient elements. Except for magnesium, the mineral nutrition showed a general increase in the macro and microelement absorption that could be related to plant growth stimulation. The application of the humic extract enhanced the plant uptake of potassium, calcium, phosphorus and increased significantly the plant uptake of nitrogen, manganese and iron. The greatest nutrient concentration of treated plant tissues was observed in roots, probably because of their direct contact with the nutrient solution (Table 6). Significant increases were observed in copper, magnesium and sulphur content in treated compared to control plants.

\section{Discussion}

The process developed to transform organic waste, generates humic-like substances under controlled and precise conditions (Morard et al., 2005; Richard, 2002). Its reproducibility attests the homogeneity of end products. According to the results reported in research literature (Chen and Aviad, 1990; Fagbenro and Agboola, 1993; Vaughan and Malcom, 1985), the positive effects of HLS were first observed on biometric factors reflecting plant growth such as the measurement of shoot and root length or fresh and dry weights for each maize organ. However, most of the studies are focused on the growth of young seedlings, and little information is available on the effect of HS on whole mature plants (the advanced development stages, i.e. flowering). Our study focuses on the effects of humic substances on whole plant development from seed to seed. In addition, few studies mentioned the impact of humic substances on

Table 6

Nutrient concentration in different plant organs

\begin{tabular}{|c|c|c|c|c|c|c|c|c|c|c|}
\hline & \multicolumn{2}{|l|}{ Roots } & \multicolumn{2}{|l|}{ Shoots } & \multicolumn{2}{|l|}{ Leaves } & \multicolumn{2}{|l|}{ Flowers } & \multicolumn{2}{|l|}{ Total } \\
\hline & Control & HLS & Control & HLS & Control & HLS & Control & HLS & Control & HLS \\
\hline \multicolumn{11}{|c|}{ Macroelements (\%) } \\
\hline $\mathrm{K}$ & $3.19 \mathrm{a}$ & $2.99 \mathrm{a}$ & $3.34 \mathrm{a}$ & $2.55 \mathrm{a}$ & $3.76 \mathrm{a}$ & $3.17 \mathrm{a}$ & - & 1.57 & $3.61 \mathrm{a}$ & $2.75 \mathrm{a}$ \\
\hline $\mathrm{Ca}$ & $1.68 \mathrm{a}$ & $2.89 \mathrm{a}$ & $0.18 \mathrm{a}$ & $0.32 \mathrm{a}$ & $0.92 \mathrm{a}$ & $0.80 \mathrm{a}$ & - & 0.18 & $0.66 \mathrm{a}$ & $0.69 \mathrm{a}$ \\
\hline $\mathrm{Mg}$ & $0.08 \mathrm{a}$ & $0.14 \mathrm{~b}$ & $0.07 \mathrm{a}$ & $0.04 \mathrm{a}$ & $0.24 \mathrm{a}$ & $0.14 \mathrm{a}$ & - & 0.06 & $0.12 \mathrm{a}$ & $0.08 \mathrm{a}$ \\
\hline $\mathrm{N}$ & $2.35 \mathrm{a}$ & $3.12 \mathrm{a}$ & $1.43 \mathrm{a}$ & $2.27 \mathrm{a}$ & $2.38 \mathrm{a}$ & $3.03 \mathrm{a}$ & - & 1.82 & $1.93 \mathrm{a}$ & $2.36 \mathrm{~b}$ \\
\hline S & $0.98 \mathrm{a}$ & $1.51 \mathrm{~b}$ & $0.25 \mathrm{a}$ & $0.08 \mathrm{a}$ & $0.74 \mathrm{~b}$ & $0.33 \mathrm{a}$ & - & 0.11 & $0.53 \mathrm{a}$ & $0.35 \mathrm{a}$ \\
\hline $\mathrm{P}$ & $1.73 \mathrm{a}$ & $1.95 \mathrm{a}$ & $0.66 \mathrm{a}$ & $0.40 \mathrm{a}$ & $0.90 \mathrm{a}$ & $0.75 \mathrm{a}$ & - & 0.18 & $0.95 \mathrm{a}$ & $0.68 \mathrm{a}$ \\
\hline \multicolumn{11}{|c|}{ Microelements $\left(m g l^{-1}\right)$} \\
\hline $\mathrm{Cu}$ & $78.7 \mathrm{a}$ & $90.2 \mathrm{~b}$ & $19.2 \mathrm{a}$ & $21.3 \mathrm{a}$ & $42.5 \mathrm{a}$ & $43.2 \mathrm{a}$ & - & 29.3 & $37 \mathrm{a}$ & $37 \mathrm{a}$ \\
\hline Mn & $421.7 \mathrm{a}$ & $451.7 \mathrm{a}$ & $60.0 \mathrm{a}$ & $56.7 \mathrm{a}$ & $658.3 \mathrm{a}$ & $511.7 \mathrm{a}$ & - & 67.5 & $290 \mathrm{a}$ & $286 \mathrm{a}$ \\
\hline $\mathrm{Zn}$ & $165.0 \mathrm{a}$ & $200.0 \mathrm{a}$ & $63.3 \mathrm{a}$ & $51.7 \mathrm{a}$ & $61.7 \mathrm{a}$ & $115.0 \mathrm{~b}$ & - & 67.5 & $84 \mathrm{a}$ & $91 \mathrm{a}$ \\
\hline $\mathrm{Fe}$ & $9320 \mathrm{a}$ & $10726 \mathrm{a}$ & $680.0 \mathrm{~b}$ & $215.0 \mathrm{a}$ & $870.0 \mathrm{a}$ & $870.0 \mathrm{a}$ & - & 387.5 & $2280 \mathrm{a}$ & $1896 \mathrm{a}$ \\
\hline
\end{tabular}


water consumption and efficiency. HLS application resulted in significantly higher water consumption, confirming a better global plant growth. Moreover, the higher water efficiency indicated that the high water consumption was associated with an improved efficiency of the biomass synthesis. These observations suggest that the plant hydrous flow is increased in the presence of the humic extract. Furthermore, the water consumption can be related to the increase of the nutrient uptake which is known to be involved in plant growth (Lulakis and Petsas, 1995; Rauthan and Schnitzer, 1981; Tan and Nopamornbodi, 1979). This hypothesis was confirmed by significant increase in nitrogen, manganese and iron uptake in treated plants. According to Pinton et al. (1999) the beneficial effects of humic substances on plant nutrition has been attributed to the promotion of root development. Our results agree with this observation, showing a higher increase in fresh and dry weight and the root elongation of treated compared to control plants. Moreover, HLS increase the lateral root emergence and induce the production of smaller but more ramified secondary roots. Similar results were noticed by other authors (Canellas et al., 2002; Hartwigsen and Evans, 2000). Taken together biometric and development factors indicate that root development induces an increase in total radicular length and enhance root surface resulting in a better mineral nutrition. The modification of the root structure underlines the beneficial effects of HLS on several stages of plant development. Many studies deal with seed germination but few results are available on the flowering or advanced vegetative stage. Concerning the effects of HLS on organ development, our results suggest an acceleration of the flowering initiation. At harvest time, only treated plants have produced male and female inflorescences and most of these plants present two cobs indicating the flowering precocity. The seed germination results emphasize also that HLS may play an important role in seed germination and root elongation which can be considered as the earlier stimulation induced by the humic molecules. The difference in growth observed between treated and control plants might be due to a different development speed. HLS seem to accelerate plant development. The number of leaves and the presence of flowers on treated plants confirm the end of the vegetative stage and the initiation of the reproductive stage. On the contrary, control plants have no flowers and a limited number of leaves indicating an earlier development stage. In the same way, the nutrient uptake does not reflect the nutrient concentration in plants. The greater nutrient absorption by treated plants can be related to their advanced development stage but this uptake does not induce significant differences in the plant nutrient concentration. Our results suggest that HLS act on plant development by increasing the precocity but also on plant growth by improving biomass synthesis efficiency. The effects on plant development considerations suggest a possible interaction (direct or indirect) with plant growth regulators. To explain these phenomena, humic molecules have previously been reported for their auxin-like activities (Bottom- ley, 1917; Muscolo et al., 1999; O’Donnell, 1972). O'Donnell (1972) showed that different humic extracts produce similar effects to IAA on root elongation. The understanding of the interaction between plant hormones and humic substances may be a key to understanding the effects of humic molecules on plant growth and development.

\section{Conclusion}

Within the experimental conditions studied, we show that HLS, as natural humic substances, demonstrate positive effects on plant growth. These results suggest that the use of HLS may generate various scientific and economic advantages. The production of HLS from the physicochemical transformation of sawdust is an interesting way of enhancing organic waste materials. Moreover, the earlier and more profuse rooting and flowering may have an interest in agricultural use considering the obvious economic benefits of an earlier harvest.

\section{Acknowledgement}

We thank Gaillard Semence SA., France, for their financial support.

\section{References}

Atiyeh, R.M., Lee, S., Edwards, C.A., Subler, S., Metzger, J.D., 2001. Pig manure vermicompost as a component of a horticultural bedding plant medium: effects on physiochemical properties and plant growth. Bioresource Technol. 78, 11-20.

Atiyeh, R.M., Lee, S., Edwards, C.A., Arancon, N.Q., Metzger, J.D., 2002. The influence of humic acids derived from earthworm-processed organic wastes on plant growth. Bioresource Technol. 84, 7-14.

Ayuso, M., Hernandez, T., Garcia, C., Pascual, J.A., 1996. Stimulation of Barley growth and nutrient absorption by humic substances originating from various organic materials. Bioresource Technol. 57, 251257

Bottomley, W.B., 1917. Some effects of organic-promotion substances (auximones) on the growth of Lema minor in mineral cultural solutions. Proc R Soc Lond Ser B Biol Sci. 89, 481-505.

Brownell, J.R., Nordstrom, G., Marihart, J., Jorgensen, G., 1987. Crop responses from two new leonardite extracts. Science of the Total Environment 62, 491-499.

Canellas, L.P., Olivares, F.L., Okorokovha-Façanha, A.I., Façanha, A.R., 2002. Humic acids isolated from earthworm compost enhance root elongation, lateral root emergence and plasma membrane $\mathrm{H}+$ ATPase activity in maize root. Plant Physiol. 130, 1951-1957.

Chen, Y., Aviad, T., 1990. Effects of humic substances on plant growth. In: MacCarthy, P., Clapp, C.E., Malcolm, R.L., Bloom, P.R. (Eds.), Humic Substances in Soil and Crop Sciences: Selected Readings. SSSA, Madison, pp. 161-186.

Chen, Y., Senesi, N., Schnitzer, M., 1977. Information provided on humic substances by E4/E6 ratios. Soil Sci. Soc. Am. J. 41, 352-358.

Cooper, R.J., Liu, C., Fischer, D.S., 1998. Influence of humic substances on rooting and nutrient content of creeping bentgrass. Crop Sci. 38, 1639-1644.

Eyheraguibel, B., Morard, P., Silvestre, J., 2002. Chemical origins of humic-like substances. 11th International Humic Substances Society Conference, Boston, MA (USA).

Eyheraguibel, B., 2004. Caractérisation des substances humiques biomimétiques. Effets sur les végétaux. Ph.D. Thesis, Institut National Polytechnique, Toulouse. 
Fagbenro, J.A., Agboola, A.A., 1993. Effect of different levels of humic acid on the growth and nutrient uptake of teak seedlings. J Plant Nutrition 16, 1465-1483.

Fernandez-Escobar, R., Benlloch, M., Barranco, D., Duenas, A., Guterrez Ganan, J.A., 1996. Response of olive trees to foliar application of humic substances extracted from leonardite. Scientia Horticulturae 66, 191-200.

Hartwigsen, J.A., Evans, M.R., 2000. Humic acids seed and substrate treatments promote seedling root development. Hort. Sci. 35, 12311233.

Lee, Y.S., Bartlett, R.J., 1976. Stimulation of plant growth by humic substances. Soil Sci. Soc. Am. J. 40, 876-879.

Linehan, D.J., 1978. Humic acid and iron uptake by plants. Plant and Soil. 50, 663-670.

Lulakis, M.D., Petsas, S.I., 1995. Effect of humic substances from vinecanes mature compost on tomato seedling growth. Bioresource Technol. 54, 179-182.

Malcolm, R.E., MacCarthy, P., 1986. Limitations in the use of commercial humic acids in water and soil research. Environ. Sci. Technol. 20, 904-911.

Mayhew, L., 2004. Humic substances in biological agriculture. Acres-USA 34 (1).

Morard, P., 1995. Les cultures végétales hors-sol. Publications agricoles, Agen.

Morard, P., Gourdon, C., Rigal, L., Prat, L., Silvestre, J., 2005. Procédé de préparation d'une composition humique artificielle et application. French Patent.

Muscolo, A., Bovalo, F., Gionfriddo, F., Nardi, S., 1999. Earthworm humic matter produces auxin-like effects on Daucus carota cell growth and nitrate metabolism. Soil Biol. Biochem. 31, 1303-1311.

Nardi, S., Pizzeghello, D., Muscolo, A., Vianello, A., 2002. Physiological effects of humic substances on higher plants. Soil Biol. Biochem. 34, $1527-1536$.

O'Donnell, R.W., 1972. The auxin-like effects of humic preparations from leonardite. Soil Sci. 116, 106-112.

Piccolo, A., Celano, G., Pietramellara, G., 1993. Effects of fractions of coal-derived humic substances on seed germination and growth of seedlings (Lactuga sativa and Lycopersicum esculentum). Biol. Fertil. Soils. 16, 11-15.

Pinton, R., Cesco, S., Lacolettig, G., Astolfi, S., Varanini, Z., 1999. Modulation of $\mathrm{NO}_{3}^{-}$uptake by water-extractable humic substances: Involvement of root plasma mebranes $\mathrm{H}^{+}$ATPase. Plant and Soil. 215, $155-161$

Rauthan, B.S., Schnitzer, M., 1981. Effects of a soil fulvic acid on the growth and nutrient content of cucumber (Cucumis sativus) plants. Plant and Soil. 63, 491-495.

Raviv, M., 1998. Horticultural uses of composted materials. Acta Hort., 225-234.

Ribeiro, H.M., Vasconcelos, E., Dos Santos, J.Q., 2000. Fertilisation of potted geranium with a municipal solid waste compost. Bioresource Technol. 73, 247-249.

Richard, J.F., 2002. Caractérisation de substances humiques-like, comparaison avec des substances humiques naturelles. Ph.D. Thesis, Institut National Polytechnique, Toulouse.

Senesi, N., 1989. Composted materials as organic fertilizers. The Science of the Total Environment, 521-542.

Schnitzer, M., Khan, S.U., 1972. Humic substances in the environment. Marcel Dekker, Newyork.

Tan, K.H., Nopamornbodi, V., 1979. Effect of different levels of humic acids on nutrient content and growth of corn (Zea mays L). Plant and Soil. 51, 283-287.

Vaughan, D., Malcom, R.E., 1985. Influence of humic substances on growth and physiological processes. In: Vaughan, D., Malcolm, R.E. (Eds.), Soil organic matter and biological activity. Dordrecht, Boston, pp. 37-75.

Vaughan, D., Ord, B.G., 1985. Soil organic matter: a perspective on its nature, extraction, turnover an role in soil fertility. In: Vaughan, D., Malcom, R.E. (Eds.), Soil organic matter and biological activity. Dordrecht, Boston, pp. 1-36.

Walkley, A., Black, I.A., 1934. An examination of degtjaref method for determining soil organic matter and a proposed modification of the chromic acid titration method. Soil Sci. 37, 29-37. 